country planning at national, regional and local levels only recently gained recognition as a necessary duty of central and local government. The first really comprehensive Town and Country Planning Act reached the Statute Book only in 1947.

Great tasks face us in Britain in reshaping large towns, modernizing urban roads and transport systems, redeveloping civic and business central areas and renewing obsolescent housing; and, in the countryside, conservation and renewal of beauty, and efficient use of land for agriculture, forestry and recreation. Much has been done in devising and developing new techniques and methods in planning, and outstanding success has been achieved in many ways, for examplc in the creation of twenty-four New Towns which are giving, or will soon give, an environment for living such as has never been enjoyed at any other time by ordinary folk. These techniques and standards are capable of adaptation for use in developing countries, and an increasing number of their nationals are attending courses in planning at British universities. This is as it should be; because planning for people is best done by those who understand them best.

\title{
REFERENCES
}

Bertaux, P. (1968). The Future of Man. In Environnent and Change [William R. Ewald Jr, editor].

Town Planning Conference, Washington D.C. 1967. Indiana: University Press.

Derry, T. K. (1965). A Short Economic History of Britain. Oxford: University Press.

Kenya Town Planning Department (1967). Central Province Study. Goverument of Kenya.

Koenigsburger, O. (1967). Planning for Rapid Change the Urban Problem. In Report of Proceedings, Town and Country Planning Summer School, 1967. London: Town Planning Institutc.

NATO (1969). Man and his Environment. NATO Letter, September, UN Report.

Richards, A. I. (1958). Problems of Urbanization and Community Development in Changing Society. In Report of Tozun and Country Planning Summer School, 1958. London: Town Planning Institute.

\section{The social, economic and marketing aspects of diffusing low-cost protein-enriched foods in urban Africa and the Third World}

\author{
By T. L. BLaIr, The Polytechnic, London, $W_{\mathrm{I}}$
}

Economic development, mass migration and rapid urban growth are three major aspects of change in Africa today (Clairmonte, 1969). The same applies to the Third World, the majority of nations and peoples of Africa, Asia and Latin America who are the poor two-thirds of the world, and in large part the clients of the major Western powers. Over the next decade there will be many important advances, but millions of new urban households will spend their lives in makeshift shanty towns prey to all the diseases of poverty and malnutrition (Abrams, I966). These sombre forecasts set the context within which a vital question must be answered: how can we diffuse low-cost nutritious foods among low-income and no-income urban households?

Finding solutions to this question will not be an easy task. It is my contention, however, that from a marketing point of view the solutions lie neither in advanced food technology alone, nor in accumulated nutritional and sociological knowledge. 
New studies of food habits and types of markets for improved foods and family diets are required. New marketing approaches are necessary. This paper, based on my experience as a researcher and consultant in West Africa, seeks to identify some important social, economic and marketing factors affecting the diffusion and acceptance of low-cost nutritious foods, both traditional and modern, among urban households.

\section{Cities and markets}

Cities in modern Africa are focal points of social and economic change (UNESCO, r956). Their rate of growth amidst the vast rural background of the continent's three hundred million people is phenomenal. Urban-dwelling Africans, some $13 \%$ of the total population, are increasing at twice the world rate and four times the continent's annual population growth.

Cities, with their industrial enterprises and wage-earning workers, are crucial arenas of contact between people and products. Industrial estates and homes blossom in the wake of bulldozers and marketing services reach out to integrate them into a world-wide economy. Traders in traditional flowing robes make their rounds by car and motor scooter. Mass media stimulate the formation of new tastes, new markets and new consumers (Blair, I965).

Markets in Africa emerge in expanding cities, mill and mining towns, seaports and affluent village settlements surrounded by rich cash crop lands. Large urban market places are located in central areas at crossroads and transport interchanges. Most people do their daily shopping at small local market places and attend a large 'Saturday' market once a week. Night markets along major streets ensure that housewives can buy a few last-minute itcms without travelling too far.

Urban market places are part of an international chain of distribution which links consumers to national and foreign sources of supply. The circulation of goods and services and the satisfaction of needs is accomplished through cash exchange and barter. Marketing behaviour is overlaid with custom. Shared systems of values regulate market transactions and bind buyers and sellers in an extended pattern of social ritual. 'Going to market' also provides a window on the world. Market places are the venue of many social activities and offer urban dwellers a glimpse through discussions and new products of the world that lies beyond their immediate experience.

\section{Changing food habits}

The market place in urban areas is a primary source of supply for daily food needs. Food choices and preferences carried over from traditional African village culture influence shopping and eating habits. The main daily meal consists of a starchy staple and stew. In West Africa, for example, rice, yams, cassava and maize are the most popular basic foods and main source of calories. Tasty stews made with such ingredients as stockfish, chicken and goat meat, beans and groundnuts provide the protein intake.

Urban dietary habits are not static, however. Consumption of processed foods is 
rising in proportion to rising household incomes and new aspirations. New food tastes and eating habits complement changes taking place toward single family households. Consumers buy more traditional foods and expensive commodities, particularly processed foods, fish and meat. Spirits, beer and mineral waters displace traditional beverages and compete for a larger share of family budgets (Blair, I.966a).

\section{The marketing challenge}

Food marketing in developing Africa faces the most challenging tasks in its history. Tomorrow's consumers will have more choices from the delicatessen of world goods available in their shops. They will be able to buy as they desire, shift brands or stop buying. What are they likely to do? How and in what direction and in what degree will the spending habits of families be influenced by family size, occupation, wages, disposable income, and future expectations? How will families spend their money? These are some of the important questions to be asked by modern marketing men (Charbonneau \& Charbonneau, I96I).

Many commercial manufacturers and distributors prominent in Africa, for example Lever Brothers and United Africa Company, are recognizing the potential market for improved food products, and there are many popular brands currently available. However, real progress in this sphere is limited. Iow-income households cannot afford the foods they need. Company managers claim they cannot produce feasible branded items at the profit margins they require. For these reasons the market is restricted to a small affluent proportion of the urban population.

\section{Key factors affecting marketing}

There is no doubt that more research and feasibility studies need to be undertaken in all aspects of food technology, production, pricing and distribution. The goal should be the production and marketing of quality-controlled research-based low-cost nutritious foods with regular prices and profit margins. Experimentation is required with a wide range of specific product research techniques, including consumer panels, attitude and motivational research, and paired comparison tests.

Basic studies of key social factors affecting marketing are also needed. And these should be initiated by a new type of market researcher with an awareness of the needs of families in transition (Blair, 1966b). Marketing managers and nutritionists as well should broaden their knowledge of five important social aspects:

(1) The differing cultural outlooks which separate the agents of food changes from consumers;

(2) The functions and dysfunctions of the chain of distribution;

(3) The role of traders and the bartering system by which goods are bought and sold from hand to hand until their utility for generating money or barter decreases.

(4) The 'irrational' factors affecting market organization, price mechanisms and division of labour, e.g. custom, taboos, bargaining etc;

(5) The patterns of information exposure and ownership and usership of mass media. 
From this point of view, introducing commercially viable food products into the African home is more than a question of creating better or cheaper products. The success of any new product will depend on a broader understanding of marketing dynamics. There must be a greater awareness and acceptance of the values of African consumers. 'I'heir palates and tables need not become mere carbon copies of Western archetypes. All existing products must be re-examined in relation to their function and appropriateness. A product's saleability should depend on whether it can compete successfully in price, quality and taste with traditional and locally produced items.

\section{Introducing protein-rich foods and supplements}

It is obvious, however, that left to market forces the food needs of the larger mass of urban low-income and unemployed householders and their dependents cannot be met. In too many cities all over the continent food hunger and malnutrition are reaching crisis proportions. It is in this context that the efforts of Western governments, voluntary organizations and international agencies have assumed a prominent role. Large-scale research programmes have created 'wonder foods'. They are the protein-enriched foods and food supplements one has heard so much about in the last decade. Their use has been confined until recently to use in supervised feeding programmes for treatment of protein-calorie malnutrition and preventively as additives to family diets.

Despite dramatic results, the diffusion and acceptance of enriched foods among urban dwellers has not reached expectations. C.S.M., the American processed corn meal, soya flour and non-fat dry milk mixture is a case in point. Without a massive corps of nutritionists and demonstrators people never learn to reconstitute it with water and mix it into their meagre diets. Children eat large quantitics of it in powdered form and get diarrhoea. Adults sell it for garri at a pound-for-pound rate. In general, protein-enriched foods dispensed under welfare and subsidized auspices have low priority on the consumers' hit parade of food.

Similar reports occur in relation to food gift programmes of enriched flour. In Eastern Nigeria, for example, people were not prepared to use donated wheat flour so a plan was devised to encourage a breadmaking industry. But potential enterpreneurs were discouraged by several factors. Flour is perishable after 3 months in tropical climates and storing is difficult. No yeast was made available to adventurous businessmen and no one thought to suggest the possible use of fermented palm wine as a substitute. In any case when thousands of loaves were eventually produced, low-income consumers resisted purchasing what was for them 'cake', a luxury normally eaten only by middle-class educated persons.

In many parts of the world, co-operation between governments and food technologists has shifted toward the establishment of food industries based on local resources presently unused for human consumption and the production of high-protein, lowcost food for the mass market. Nutritionists concerned with this aspect suggest that the food product should have the following characteristics: 
(I) Content: a rich protein concentrate.

(2) Uses: as a food additive or when reconstituted as a complete food in itself.

(3) Raw materials: locally available sources, e.g. oilseed meals, fish and algae.

(4) Manufacture: commercially feasible.

(5) Marketing: inexpensive, non-perishable, culturally acceptable, easily adaptable to existing food habits and tastes.

But there are additional limitations to this approach. These sources are finite. Nothing on the horizon ensures that production of conventional agricultural and marine crops will be sufficient to match the population growth and future needs of the developing nations. As a result, attention has turned towards the production of single-cell protein which, in contrast to oilseeds and fish for example, does not either require agricultural land or threaten the survival of species. The problems and prospects of this new approach will unfold as pilot projects get under way in the next decade (Blair, I968). The essential marketing questions remain the same, nevertheless. How to place low-cost nutritious foods into the diets of low-income families: in what way, in what form and at what price? What are the correct marketing strategies, consumer benefits and competitive qualities of these products compared with others? How is it possible to shift the 'selling message' from social welfare concepts to modern marketing concepts?

One step in the right direction would be the formulation of a six-stage basic research programme to identify the potential for new foods, to locate target consumer groups and to establish the marketing arguments for new forms of branded highprotein, low-cost products (Blair, 1969). Briefly the main stages are:

(I) Desk research and analysis of statistical information relating to occupational groups, household income and expenditure, family budgets, etc.

(2) Sociological field surveys of family structure, decision-making and the feeding patterns of mothers and children in low-income and upper-income families.

(3) Depth study of two potential markets (a) low-cost foods for low-income and no-income families, and (b) quality foods for upper-income families which are competitive in price with imported foodstuffs.

(4) Formulation of new food products and specific selling propositions.

(5) Market research and test marketing to discover the appropriate selling platforms, product forms and means of communication.

(6) Debriefing of the process after the product is launched to study consumer usage and satisfaction and to obtain other feed-back and feed-forward information affecting product technology, design and distribution.

\section{The food question and rural development}

It would be remiss of me to conclude without saying that it is in the interests of African governments and peoples to make every effort to relate food programmes to the quest for rural development. No matter how many nutritious foods are placed in urban homes, there are still the needs of the vast rural population to be considered. It is my feeling that in the long term the emphasis in African nations must be on the establishment of adequate agricultural programmes serving internal markets, and 
that in the short-term major efforts should be made to cut wastage and to increase the amount and quality of foods presently eaten by low-income families.

Looked at in this way rural development and the conquest of urban food problems are related by agricultural development within the framework of real national economic development. In West Africa, for example, it is easier to get a low-income worker to eat additional quantities of higher-protein foodstuffs known to him, for example cereal, cassava leaves, fish or meat, than it is to ask him to stop eating cassava and to switch to new foods. Where there is a choice, consumption of cereals should be encouraged over that of yams or cassava because they have a higher nutritional value, can be handled more easily and stored longer. Stockfish, though imported in large quantities from Scandinavian countries, has been in use for decades, and its continued use should be encouraged. It is popular, has a high nutritional value, is easy to transport, stores well and compares favourably in price with locally produced protein-containing food.

Meeting food needs is a political question in Africa and the rhird World, one which is linked to complex problems of trade, international diplomacy and the balance of payments. More powerful nations than they are in a dominant position. It is recognized that many food gift programmes are often launched to aid the donors' surplus food problcms or to create a dependent client-donor relationship. From the point of view of African governments, therefore, it is necessary to scrutinize all nutritional plans, all products and all aid programmes in terms of their net social benefit, that is the contribution they make to building healthy nations and independent, increasingly self-sufficient and just economies.

\section{REFERENCES}

Abrams, C. (1966). Housing in the Modern World. London: Faber and Faber.

Blair, T. L. (1965). Africa, A Market Profle. London: Business Publications Ltd. New York: F. J. Praeger.

Blair, T. I. V. (1966a). Fd Technol., Champaign 20, 757.

Blair, T. L. (1 9666 ). Inter-Economics. Hamburg: Institute for International Economics.

Blair, T. L. (1968). In Single-Cell Protein [R. I. Mateles and S. R. Tannenbaum, editors]. Cambridge, Mass: The Massachusetts Institute of Technology Press.

Blair, T. L. (1969). In Protein-Enriched Cereal Foods in Africa [Max Milner, editor]. St. Paul, Minnesota: The American Association of Cereal Chemists.

Charbonneau, J. \& Charbonneau, R. (1961). Marchés et Marchands d'Afrique Noire. Paris: La Colombe.

Clairmonte, F. (1969). In Africa Handbook [C. Legum, editor]. I ondon: Penguin Reference Books.

UNESCO (1956). Social Implications of Industrialization and Urbanization in Africa South of the Sahara. Paris: UNESCO Tensions and Technology Series.

\section{Food supplies for urban populations in developing countries}

\section{By F. Aylward, Department of Food Science, University of Reading}

Although there is a large and growing literature devoted to rural communities in the developing world, there are far fewer publications dealing directly with the problems-including the food, nutrition and health problems-of the expanding urban populations. Many of the capitals and other cities of the newer African nations 